\title{
Weathering processes and dating of soil profiles from São Paulo State, Brazil, by U-isotopes disequilibria
}

\author{
Daniel Marcos Bonotto*, Jairo Roberto Jiménez-Rueda, Isabella Cruz Fagundes, \\ Carlos Roberto Alves Fonseca Filho
}

Departamento de Petrologia e Metalogenia, Universidade Estadual Paulista (UNESP), Câmpus de Rio Claro, Av. 24-A No.1515, C.P. 178, CEP 13506-900, Rio Claro, São Paulo, Brasil

\section{A R T I C L E I N F O}

\section{Keywords:}

Uranium isotopes

Soil profiles

Weathering processes

Dating

Paraná sedimentary basin

\begin{abstract}
A B S T R A C T
This study reports the use of the U-series radionuclides ${ }^{238} \mathrm{U}$ and ${ }^{234} \mathrm{U}$ for dating two soil profiles. The soil horizons developed over sandstones from Tatuí and Pirambóia formations at the Paraná sedimentary basin, São Paulo State, Brazil. Chemical data in conjunction with the ${ }^{234} \mathrm{U} /{ }^{238} \mathrm{U}$ activity ratios (AR's) of the soil horizons allowed investigating the U-isotopes mobility in the shallow oxidizing environment. Kaolinization and laterization processes are taking place in the profiles sampled, as they are especially common in regions characterized by a wet and dry tropical climate and a water table that is close to the surface. These processes are implied by inverse significant correlations between silica and iron in both soil profiles. Iron oxides were also very important to retain uranium in the two sites investigated, helping on the understanding of the weathering processes acting there. ${ }^{238} \mathrm{U}$ and its progeny ${ }^{234} \mathrm{U}$ permitted evaluating the processes of physical and chemical alteration, allowing the suggestion of a possible timescale corresponding to the Middle Pleistocene for the development of the more superficial soil horizons.
\end{abstract}

\section{Introduction}

Uranium is a lithophile element that is among the main elements contributing to natural terrestrial radioactivity, together with thorium and potassium $\left({ }^{40} \mathrm{~K}\right)$. The two natural $\mathrm{U}$-isotopes ${ }^{238} \mathrm{U}$ and ${ }^{235} \mathrm{U}$ are precursors of the natural mass number $4 n+2$ and $4 n+3$ decay series, respectively. The third natural $\mathrm{U}$-isotope, ${ }^{234} \mathrm{U}$, is radiogenic and generated in the ${ }^{238} \mathrm{U}$ decay chain according to the sequence: ${ }^{238} \mathrm{U}$ $(4.46 \mathrm{Ga}, \alpha) \rightarrow{ }^{234} \mathrm{Th}\left(24.1\right.$ days, $\left.\beta^{-}\right) \rightarrow{ }^{234} \mathrm{~Pa}(1.18 \mathrm{~min}, \alpha) \rightarrow{ }^{234} \mathrm{U}(248$ ka, $\alpha) \rightarrow \ldots{ }^{206} \mathrm{~Pb}$. The variation of the number of radionuclides per time unit in this series is:

$d N_{1}=-\lambda_{1} N_{1} d t$

$d N_{2}=\left(\lambda_{1} N_{1}-\lambda_{2} N_{2}\right) d t$

$d N_{3}=\left(\lambda_{2} N_{2}-\lambda_{3} N_{3}\right) d t$

$d N_{i}=\left(\lambda_{i-1} N_{i-1}-\lambda_{i} N_{i}\right) d t$

where: $N_{i}$ corresponds to the number of disintegrations associated to the $i$-th nuclide of the decay series in time $t$ and $\lambda_{i}$ is its respective decay constant. If the notation " $o$ " represents the initial condition at time $t=0$, on the assumption that ${N_{2}}^{0}=0$ and when $\lambda_{2}>>\lambda_{1}$, the solution of the second equation from (1) provides the number of radionuclides produced by the radioactive decay of their parent, i.e.:
$N_{2}=\lambda_{1} N_{1}^{0}\left[1-\exp \left(-\lambda_{2} t\right)\right] / \lambda_{2}$

If the system exists for a long time $(t \rightarrow \infty)$, then, Eq. (2) may be simplified so that the number of atoms produced remains unaltered, allowing a re-write of Eq. (1) to the situation named Secular Radioactive Equilibrium in which the number of atoms disintegrating per time unit is equal to that formed at the same time interval, also expressed as:

$\lambda_{1} N_{1}=\lambda_{2} N_{2}=\lambda_{3} N_{3}=\ldots \ldots=\lambda_{i} N_{i}$

Thus, if radioactive equilibrium occurs within the ${ }^{238} \mathrm{U}$ decay series, the radionuclides activities are equal. In closed systems, not subjected to weathering processes, ${ }^{234} \mathrm{U}$ reaches radioactive equilibrium with ${ }^{238} \mathrm{U}$ and $\lambda_{238} N_{238}=\lambda_{234} N_{234}$ (the notation "238" refers to ${ }^{238} \mathrm{U}$ and " 234 " to ${ }^{234} \mathrm{U}$ ). Therefore, the ${ }^{234} \mathrm{U} /{ }^{238} \mathrm{U}$ activity ratio (AR) is unity in the bulk of such systems. Because $\lambda_{238}<<\lambda_{234}$, Eq. (2) modified allows an estimate of the time for the establishment of the radioactive equilibrium between them, that is:

$t=-\ln \left[1-\lambda_{234} N_{234} / \lambda_{238} N_{238}\right] / \lambda_{234}$

Eq. (4) is unsolved under radioactive equilibrium conditions $(A R$ $=1$ ), but if $A R=0.97$, then, $t=3.5 / \lambda_{234}$, implying the return to secular equilibrium over a timescale of circa 5 half-lives of the daughter

\footnotetext{
* Corresponding author.

E-mail address: danielbonotto@yahoo.com.br (D.M. Bonotto).
} 
nuclide. Thus, ${ }^{234} \mathrm{U}$ needs $\sim 1.2$ Ma to reach radioactive equilibrium with ${ }^{238} \mathrm{U}$ in closed systems consisting of many minerals and rocks. Latham and Schwarcz (1987), Ivanovich and Harmon (1992), and Suresh et al. (2013), among others, have discussed these concepts elsewhere.

Water/rock-soil interactions frequently result in AR's $>1$ for dissolved uranium and AR's $<1$ in the solid phase, mainly porous matrices (Osmond and Cowart, 1976; Ivanovich and Harmon, 1992). Alternative mechanisms may explain the disequilibria conditions affecting ${ }^{238} \mathrm{U}$ and ${ }^{234} \mathrm{U}$ in natural systems. For instance, Rosholt et al. (1963) proposed the occurrence of enhanced chemical solution of ${ }^{234} \mathrm{U}$ due to radiation damage of crystal lattices or to autoxidation from $\mathrm{U}^{4+}$ to $\mathrm{U}^{6+}$ on decay of the parent ${ }^{238} \mathrm{U}$. Other significant early works in the 1960s demonstrated that a process of isotopic evolution of $U$ and Th occurs in most types of sediments, altered volcanic ashes and deeply buried granites provided that some groundwater is allowed to migrate through the porous zones of these materials during their geologic history (Rosholt et al., 1966). Additionally, Hansen and Stout (1968) found that three soil profiles developed upon glacial till and loess contained excess ${ }^{230} \mathrm{Th}$ and quantities of ${ }^{234} \mathrm{U}$ slightly less than quantities of ${ }^{238} \mathrm{U}$. Hansen and Stout (1968) proposed a model for migration of ${ }^{238} \mathrm{U}$ and ${ }^{234} \mathrm{U}$ in other soils, showing that ${ }^{234} \mathrm{U}$ was leached more readily than ${ }^{238} \mathrm{U}$ in the early stages of rock weathering, whereas some ${ }^{234} \mathrm{U}$ in excess of ${ }^{238} \mathrm{U}$ accumulated in the topsoils of two soils of high organic content. In the 1970s, the experiments performed by Kigoshi (1971) and Fleischer and Raabe, (1978a, 1978b) showed that alpha-particle recoil ejection of the ${ }^{234} \mathrm{U}$ precursor, ${ }^{234} \mathrm{Th}$, into solution may also generate enhanced ${ }^{234} \mathrm{U} /{ }^{238} \mathrm{U}$ activity ratios in the liquid phase.

The parameter time of processes controlling the formation and evolution of soils and weathering profiles is a key information to be determined for many questions of the Earth and Environmental Sciences (Chabaux, 2010). Under this perspective, equilibrium and disequilibrium conditions affecting ${ }^{238} \mathrm{U}$ and ${ }^{234} \mathrm{U}$ have been extensively used by the researchers since the 1960s. The interest of U-series nuclides as tracers and chronometers of weathering processes results from the dual property of the nuclides to be fractionated during waterrock/soil interactions and to have radioactive periods of the same order of magnitude as the time constants of many weathering processes (Chabaux, 2010). Different approaches have been utilized for the application of U-series nuclides to the study of weathering processes like those reported by Ivanovich and Harmon (1992), Dequincey et al. (2002), Chabaux et al. (2003, 2006, 2008), Van Carlsteren and Thomas (2006), Bernal et al. (2006), Dosseto et al. (2008), etc.

Some previous studies have been already conducted in the tropical conditions of Brazil using the U-series nuclides as those performed by Chabaux et al. (2006), Bonotto and Jiménez-Rueda (2007), Bonotto et al. (2007), Conceição and Bonotto (2003), and others. However, the use of ${ }^{238} \mathrm{U}$ and ${ }^{234} \mathrm{U}$ for evaluating weathering processes occurring in horizons of soil profiles is still incipient compared to the large extension of the exposed soil covers in the country. Soils occurring at the giant Paraná sedimentary basin, South America, are very important resources, as they have been extensively used for agricultural purposes, among other. This paper reports the results of chemical analysis of the major constituents and both U-isotopes ${ }^{238} \mathrm{U}$ and ${ }^{234} \mathrm{U}$ in samples of two soil profiles developed over sandstones from the Paraná basin in São Paulo State, Brazil, for investigating the timescale of the weathering processes taking place there.

\section{Study area}

The soil profiles were sampled close to Piracicaba and Rio Claro cities almost in the center of São Paulo State, Brazil (Fig. 1). The soil profile 1 was situated about $8 \mathrm{~km}$ distant from Piracicaba city by the SP-304 highway that connects Piracicaba and Santa Bárbara d'Oeste cities. The soil profile 2 was situated circa $10 \mathrm{~km}$ distant from Rio Claro city by an unpaved road giving access to sugar cane plantations in the region that is connected to SP-191 highway between Rio Claro and Araras cities. Profile 1 is located in the Piracicaba River basin that belongs to major hydrographic Piracicaba/Capivari/Jundiaí basin and is inserted in the Depressão Periférica Paulista geomorphological unit (IPT, 1981). Profile 2 was also sampled in the same geomorphological unit but in an area whose main drainage systems are represented by the Corumbataí River, belonging to Piracibaba/Capivari/Jundiaí hydrographic basin and the Araras River that belongs to Moji-Guaçu hydrographic basin.

In the geological context, both profiles are situated within the Paraná sedimentary basin that constitutes a geotectonic unit established over the South American Platform since the Lower Devonian or Silurian (IPT, 1981). It is located between parallels $10^{\circ}-20^{\circ}$ southern latitude and meridians $47^{\circ}-64^{\circ}$ western longitude. Its surface area corresponds to $1.6 \times 10^{6} \mathrm{~km}^{2}$, comprising southern Brazil $\left(1 \times 10^{6} \mathrm{~km}^{2}\right.$ in the states of Mato Grosso, Mato Grosso do Sul, Goiás, Minas Gerais, São Paulo, Paraná, Santa Catarina and Rio Grande do Sul), eastern Paraguay $\left(0.1 \times 10^{6} \mathrm{~km}^{2}\right)$, NW Uruguay $\left(0.1 \times 10^{6} \mathrm{~km}^{2}\right)$ and the northeastern extreme corner of Argentina $\left(0.4 \times 10^{6} \mathrm{~km}^{2}\right)$.

Both soil profiles studied in this research are described in Table 1 and Fig. 2. The horizons from soil profile 1 were deposited above the Permian sediments of the Tatuí Formation (Daemon and Quadros, 1970) whose lithology was formed from the sediments of the postglaciation period (Itararé Group) and it is mainly characterized by siltstones (Gimenez, 1996). Its thickness is less than $30 \mathrm{~m}$ in the study area that is typical in the northeast portion of the Paraná basin (Soares and Landim, 1973). The lowest part of the Tatuí Formation is characterized by siltstones and reddish green sandstones with plainparallel stratification as pointed out by Fúlfaro et al. (1984) in a statigraphic section in the south of Piracicaba city. Fúlfaro et al. (1984) also verified that its upper part presents thin reddish sandstones with crossed stratifications that change to greenish grey and yellow sandstones of medium grain size in contact with clayey siltstones.

The horizons from soil profile 2 were deposited above the Pirambóia Formation (Table 1). It is a sedimentary unit of expressive occurrence in central eastern São Paulo State, whose deposition period was between the Lower Triassic and Upper Jurassic (Soares and Landim, 1973). The Lower Member presents clayey facies of planeparallel and crossed slotted stratification, whereas the Upper Member is characterized by the presence of little to very clayey sandstone benches with plane-tangential crossed stratification of small to mean size.

\section{Sampling and analytical methods}

In the field, approximately $2 \mathrm{~kg}$ of material was collected in each horizon of the soil profiles that exhibited different thickness, i.e. $\sim 20 \mathrm{~m}$ (profile 1) and $1.2 \mathrm{~m}$ (profile 2). They were described and classified in situ according to Munsell (1994) and IBGE (2007) (Table 1 and Fig. 2). The presence of plintites (Federici and Pappalardo, 2001) enriched in iron oxides were identified in both soil profiles (Table 1). They have been supplied by oxidation and reduction alternately occurring as a consequence of periodical oscillation of the water table over the years, thus indicating long exposure to a warm and damp climate, typically tropical, for a time span long enough to permit the soil evolution (Federici and Pappalardo, 2001). Two plintites developed over Pirambóia Formation were sampled in profile 2 with a 4 "-manual auger that reached the deepest horizons and recovered an amount smaller than $2 \mathrm{~kg}$ that was also enough for the chemical and U-isotopes analyses. In profile 2, rock chips (chip sampling) were collected along the outcrop, where fractures with preponderant N45W direction were identified.

The samples were placed in plastic bags, transported to the laboratory, sieved to $2 \mathrm{~mm}$ for removing roots, leaves and other coarse materials. Then, they were crushed, quartered, sieved for separation of 


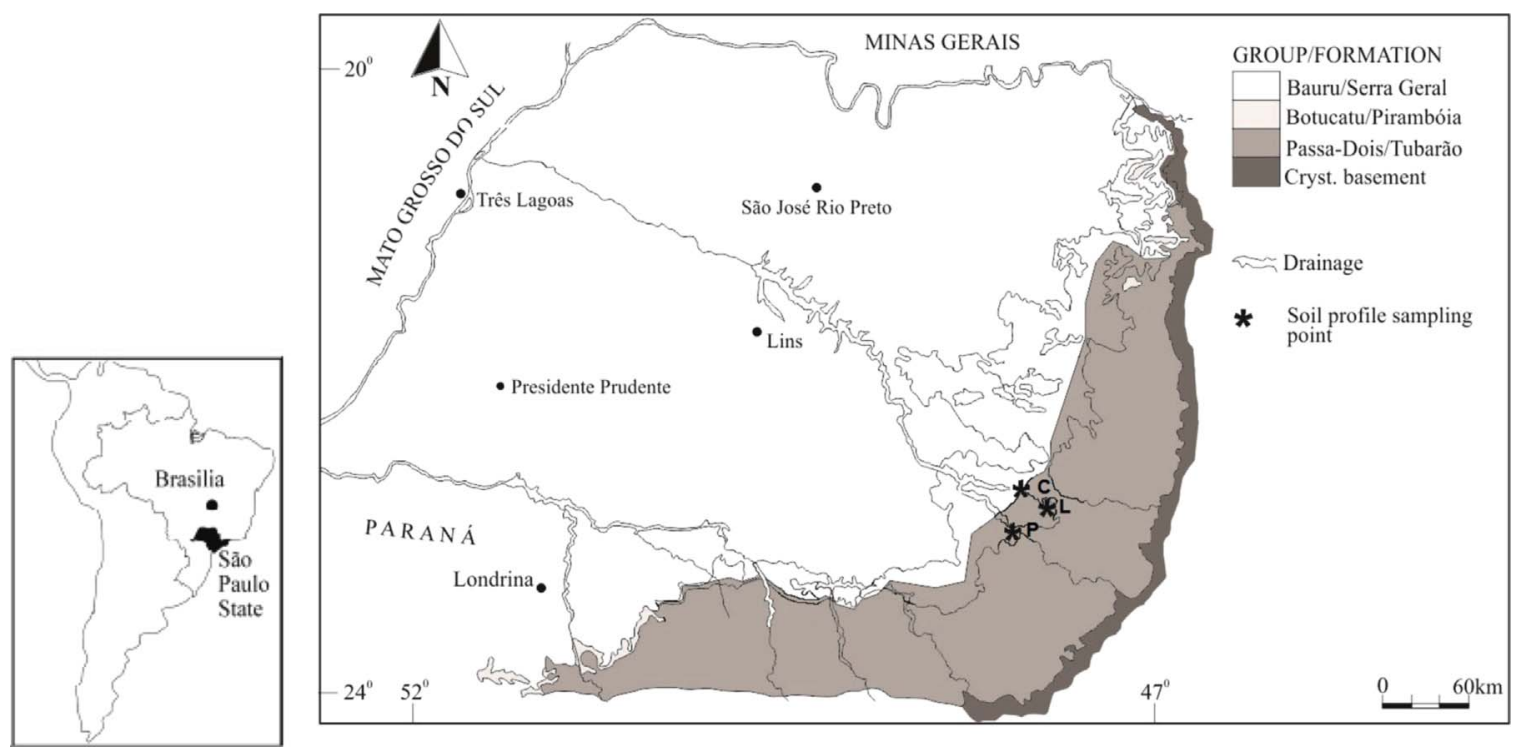

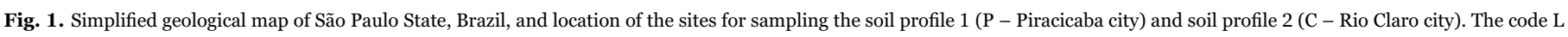
corresponds to Limeira city where Bonotto and Jimenez-Rueda (2007) sampled a soil profile developed over the Itararé Subgroup.

the $<200$ mesh $(<74 \mu \mathrm{m})$ size fraction, and divided into different aliquots for analysis of major oxides $\left(\mathrm{SiO}_{2}, \mathrm{Na}_{2} \mathrm{O}, \mathrm{K}_{2} \mathrm{O}, \mathrm{CaO}, \mathrm{MgO}\right.$, $\mathrm{Al}_{2} \mathrm{O}_{3}, \mathrm{Fe}_{2} \mathrm{O}_{3}, \mathrm{MnO}, \mathrm{TiO}_{2}, \mathrm{P}_{2} \mathrm{O}_{5}$ ), loss on ignition (LOI), organic matter $(\mathrm{OM})$, and U-isotopes. The major oxides were determined in a $5 \mathrm{~g}$ aliquot by the X-ray fluorescence method with a Philips PW 2400 spectrometer operating at $60 \mathrm{kV}, 50 \mathrm{~mA}$ and $3 \mathrm{~kW}$ as maximum voltage, current and power, respectively. The weight loss of the samples after their burning at selected temperatures and the chemical balance (in percentage) provided the LOI data (Reiche, 1943). OM was evaluated by spectrophotometry (Hach, 1992) held in a solution obtained after adding potassium dichromate and sulfuric acid to $1 \mathrm{~g}$ powdered aliquot not submitted to digestion; organic carbon was oxidized to carbon dioxide with a parallel reduction of hexavalent chromium to trivalent chromium and an accompanying color change from orange to green read at $610 \mathrm{~nm}$ (Hach, 1992).

The aliquots (between 1 and $3 \mathrm{~g}$ ) for the U-isotopes analysis were digested with aqua regia $\left(1: 3 \mathrm{HNO}_{3}-\mathrm{HCl}\right)$. Then, a $3.39 \mathrm{dpm}$ of ${ }^{232} \mathrm{U}$ spike was added into solution. After dryness and dissolution in $8 \mathrm{M}$ $\mathrm{HCl}, \mathrm{Fe}^{3+}$ was extracted into an equal volume of isopropyl ether. Then, the acid U-bearing solution was purified by anion exchange, first on a $\mathrm{Cl}^{-}$and then on a $\mathrm{NO}_{3}{ }^{-}$column of 50-100 mesh Rexyn 201 resin. U was finally eluted from the $\mathrm{NO}_{3}{ }^{-}$column with $0.1 \mathrm{M} \mathrm{HCl}$ and after evaporation to dryness was dissolved in $10 \mathrm{~mL}$ of $2 \mathrm{M}\left(\mathrm{NH}_{4}\right)_{2} \mathrm{SO}_{4}$ electrolyte and transferred to an electrodeposition cell. The $\mathrm{pH}$ was adjusted to 2.4 and electrodeposition of $\mathrm{U}$ on a stainless steel planchet was complete after $3 \mathrm{~h}$ at a current density of $1 \mathrm{Acm}^{-2}$.

The $\mathrm{U}$ content was measured by alpha spectrometry. The $\mathrm{a}-$ activities were determined with four $0.1 \mathrm{~mm}$ depletion depth, 200/ $450 \mathrm{~mm}^{2}$ area silicon surface barrier detectors. The spectra for natural $\mathrm{U}$ and ${ }^{232} \mathrm{U}$ tracer extracted were recorded on an EG \& G ORTEC 919 Spectrum Master Multichannel Buffer. The Decision Level $\mathrm{L}_{\mathrm{c}}$ (Currie, 1968) for acceptance of a positive measurement in the ${ }^{238} U$ and ${ }^{232} U$ energy regions was 0.00082 and $0.00225 \mathrm{cpm}$, respectively. The $\mathrm{U}$ concentration was calculated by isotope dilution from the counting rates of ${ }^{238} \mathrm{U}$ and ${ }^{232} \mathrm{U}$ peaks, whereas the ${ }^{234} \mathrm{U} /{ }^{238} \mathrm{U}$ activity ratio from the counting rates of ${ }^{238} \mathrm{U}$ and ${ }^{234} \mathrm{U}$ peaks. More analytical details for these measurements were reported elsewhere, e.g. Ivanovich and Harmon (1992).

\section{Results and discussion}

\subsection{Chemical composition of the soil horizons}

The $\mathrm{SiO}_{2}$ content of the sandstones of Tatuí and Pirambóia formations was high, respectively, $88 \%$ and $91 \%$, the same occurring for plintites PL-01 and PL-02 in profile 1 (84-85\%) (Table 2). Silica was also the major oxide of practically all horizons of both soil profiles, except in Crf nodular (profile 1) and $\mathrm{Fm}-\mathrm{G} / 4 \mathrm{Fm}-\mathrm{H}_{2}$ (profile 2) in which $\mathrm{Fe}_{2} \mathrm{O}_{3}$ was dominant (41-46\%) (Table 2).

The insertion of the chemical data obtained for the analyzed samples in the soil profile 2 in the $\mathrm{SiO}_{2}-\mathrm{Al}_{2} \mathrm{O}_{3}-\mathrm{Fe}_{2} \mathrm{O}_{3}$ triangle proposed by Balasubramaniam et al. (1983) for defining the presence of ferrite, bauxite, and kaolin (Fig. 3) shows that kaolinization processes are taking place in the horizons, except in the two deepest ones, which suffered laterization processes. The plintites (PL-01 and PL-02) and the rock matrix (R) samples (Table 1) suffered intense kaolinization processes. They occur by supergene autochthonous weathering and hydrothermal alteration and are prevalent in pluvial, wet and dry (savannah) tropical climate, whilst their related soils include laterite, bauxite and peat (Pohl, 2011). Laterization is also especially common in tropical regions that have a pronounced dry season and a water table that is close to the surface (Schellmann, 1979). It is a prolonged process of chemical weathering which produces a wide variety in the thickness, grade, chemistry and ore mineralogy of the resulting soils. The initial products of weathering are essentially kaolinized rocks and the laterites formed from the leaching of the parent soils and rocks are related to depletion of soluble substances such as silica-rich and alkaline components and enhancement of the more insoluble ions, predominantly iron and aluminum (Schellmann, 1979; Balasubramaniam et al., 1983; Tardy, 1997; Pohl, 2011). These processes are implied by inverse significant correlations between silica and iron in both soil profiles studied in this research (Fig. 4).

Several chemical-weathering indices exist for summarizing and condensing the cumbersome array of raw data like bases $(\mathrm{MgO}+\mathrm{CaO}$ $\left.+\mathrm{Na}_{2} \mathrm{O}+\mathrm{K}_{2} \mathrm{O}\right)$ or $\mathrm{R}_{2} \mathrm{O}_{3}\left(\mathrm{Al}_{2} \mathrm{O}_{3}+\mathrm{Fe}_{2} \mathrm{O}_{3}+\mathrm{TiO}_{2}\right)$ that have been widely utilized elsewhere (Reiche, 1943; Colman, 1982). Table 2 reports the bases and $\mathrm{R}_{2} \mathrm{O}_{3}$ as evaluated from the chemical composition of the horizons developed in soil profile 2. There is a significant inverse correlation between silica and $\mathrm{R}_{2} \mathrm{O}_{3}$ (Fig. 4) as a consequence of the relationships between silica and iron as already pointed out. In the same profile, other significant correlations were found involving these 
Table 1

Horizons description of the two soil profiles sampled at São Paulo State, Brazil.

\begin{tabular}{llll}
\hline $\begin{array}{l}\text { Depth } \\
\text { (m) }\end{array}$ & Horizon & Description & $\begin{array}{l}\text { Munsell } \\
(1994)\end{array}$ \\
& & & Color \\
& & & \\
& &
\end{tabular}

\section{Soil Profile 1 - Piracicaba city}

\begin{tabular}{|c|c|c|c|c|}
\hline $\begin{array}{c}0.00- \\
0.10\end{array}$ & Ap & $\begin{array}{l}\text { Horizon with human } \\
\text { influence. }\end{array}$ & & \\
\hline $\begin{array}{c}0.10- \\
0.60\end{array}$ & $\mathrm{Bt}_{1}$ & $\begin{array}{l}\text { Presence of saline } \\
\text { concretions; } \\
\text { irregular and clear } \\
\text { transition. }\end{array}$ & $10 \mathrm{R} 3 / 3$ & Rust red \\
\hline $\begin{array}{c}0.60- \\
2.06\end{array}$ & 2Bticn & $\begin{array}{l}\text { Coal presence; } \\
\text { diffuse and irregular } \\
\text { transition. }\end{array}$ & $10 \mathrm{R} 3 / 3$ & Rust red \\
\hline $\begin{array}{c}2.06- \\
3.30\end{array}$ & $\mathrm{Ctcn}_{1}$ & $\begin{array}{l}\text { Presence of soil } \\
\text { pebbles; irregular, } \\
\text { clear and wavy } \\
\text { transition. }\end{array}$ & & \\
\hline $\begin{array}{c}3.30- \\
4.62\end{array}$ & 3Biten & $\begin{array}{l}\text { Coal presence; } \\
\text { irregular and diffuse } \\
\text { transition. }\end{array}$ & $10 \mathrm{R} 3 / 3$ & Rust red \\
\hline $\begin{array}{c}4.62- \\
6.40\end{array}$ & 4Bten & $\begin{array}{l}\text { Bt incipient; light } \\
\text { clayey with the } \\
\text { presence of small } \\
\text { concretions; very } \\
\text { friable and } \\
\text { moderately } \\
\text { structured; massive } \\
\text { that breaks into } \\
\text { large prisms; } \\
\text { irregular and diffuse } \\
\text { transition. }\end{array}$ & $10 \mathrm{R} 3 / 6$ & Dark red \\
\hline $\begin{array}{c}6.40- \\
7.16\end{array}$ & $\mathrm{Ct}_{2}$ & $\begin{array}{l}\text { Matrix where are } \\
\text { found the soil } \\
\text { pebbles. }\end{array}$ & $10 \mathrm{R} 4 / 8$ & Red \\
\hline $\begin{array}{c}6.40- \\
7.16\end{array}$ & Pedolith & $\begin{array}{l}\text { Paleocutans between } \\
2 \text { and } 3 \mathrm{~cm} \text { of } \\
\text { diameter generated } \\
\text { from soil that } \\
\text { contained diabases } \\
\text { and quartz; probable } \\
\text { erosion from a } \\
\text { latosol to a clayey } \\
\text { soil and transported } \\
\text { by water due to their } \\
\text { rounded and } \\
\text { subrounded forms; } \\
\text { presence of } \\
\text { ferruginous and } \\
\text { hyaline quartz, } \\
\text { subrounded to } \\
\text { rounded laterites, } \\
\text { and dark metallic } \\
\text { minerals. }\end{array}$ & $10 \mathrm{R} 3 / 4$ & Rust red \\
\hline $\begin{array}{c}7.16- \\
7.54\end{array}$ & Fm nodular & $\begin{array}{l}\text { Ferruginous reversal } \\
\text { of clays formation; } \\
\text { laterites presence; } \\
\text { re-laterization. }\end{array}$ & & \\
\hline $\begin{array}{c}7.54- \\
8.76\end{array}$ & Crf nodular & $\begin{array}{l}\text { Kaolinization; re- } \\
\text { laterization. }\end{array}$ & & \\
\hline $\begin{array}{c}8.76- \\
9.74\end{array}$ & $\operatorname{Rrg}$ & $\begin{array}{l}\text { Kaolinization; } \\
\text { laterites presence; } \\
\text { flower N30E } \\
\text { faulting. }\end{array}$ & & \\
\hline $\begin{array}{c}8.76- \\
9.74\end{array}$ & CrfBtg & $\begin{array}{l}\text { Gleyzation; clay skin } \\
\text { presence; ferric } \\
\text { argillation, } \\
\text { goethization, } \\
\text { kaolinization; } \\
\text { bissialitic reversal of } \\
\text { genesis; faulting in } \\
\text { the E-W direction } \\
\text { with N60E dip. }\end{array}$ & $\begin{array}{l}5 \mathrm{Y} 6 / 1 \text { to } \\
7 / 1\end{array}$ & $\begin{array}{l}\text { Grey to light } \\
\text { grey }\end{array}$ \\
\hline $\begin{array}{c}8.76- \\
9.74\end{array}$ & Rrft & Kaolinization. & & \\
\hline $9.74-$ & Crf & Plintite formation; & $5 \mathrm{R} 6 / 5$ & Pale to light red \\
\hline
\end{tabular}

Table 1 (continued)

\begin{tabular}{|c|c|c|c|c|}
\hline $\begin{array}{l}\text { Depth } \\
\text { (m) }\end{array}$ & Horizon & Description & $\begin{array}{l}\text { Munsell } \\
\text { (1994) } \\
\text { code }\end{array}$ & Color \\
\hline 19.76 & & $\begin{array}{l}\text { kaolinization; plain- } \\
\text { parallel layers of the } \\
\text { coarse materials, 5- } \\
10 \mathrm{~cm} \text { spaced with } \\
\mathrm{N} 50 \mathrm{E} \text { vertical, N30E } \\
\text { vertical and N15E } \\
\text { vertical dips. }\end{array}$ & & \\
\hline $\begin{array}{c}9.74- \\
19.76\end{array}$ & Rrf & $\begin{array}{l}\text { Plintite formation; } \\
\text { kaolinization; plain- } \\
\text { parallel strips in the } \\
\text { N-S direction, with } \\
\text { N10E to SE15 dip } \\
\text { and E-W fracture } \\
\text { with N10 or 50E dip. }\end{array}$ & $\begin{array}{l}5 \text { YR } 5 / 8 \text { to } \\
7.5 \text { YR } 5 / 8 \\
5 \text { YR } 8 / 1 \\
\text { to } 8 / 4\end{array}$ & $\begin{array}{l}\text { Reddish yellow } \\
\text { to dark brown } \\
\text { and white to } \\
\text { light pink }\end{array}$ \\
\hline $\begin{array}{c}19.76- \\
20.50\end{array}$ & $\mathrm{R}$ & $\begin{array}{l}\text { Fault in the E-W } \\
\text { direction with N70E } \\
\text { vertical dip; } \\
\text { sandstone blocks } \\
\text { from Tatuí } \\
\text { Formation } \\
\text { frequently spaced 5- } \\
10 \mathrm{~cm} \text { and in the } \\
\text { shape of diamonds. }\end{array}$ & & $\begin{array}{l}\text { Inside - greyish } \\
\text { Outside - } \\
\text { reddish due to } \\
\text { ferruginization }\end{array}$ \\
\hline \multicolumn{5}{|c|}{ Soil Profile 2 - Rio Claro city } \\
\hline $\begin{array}{c}0.00- \\
0.06\end{array}$ & Ap & $\begin{array}{l}\text { Horizon with human } \\
\text { influence. }\end{array}$ & & \\
\hline $\begin{array}{c}0.06- \\
0.15\end{array}$ & $\mathrm{AB}$ & $\begin{array}{l}\text { Massive with N56W, } \\
\text { N84W, and N45W } \\
\text { fractures; very } \\
\text { frequent thin roots; } \\
\text { gradual wavy limit. }\end{array}$ & 5YR $3.5 / 4$ & $\begin{array}{l}\text { Reddish brown } \\
\text { to dark reddish } \\
\text { brown }\end{array}$ \\
\hline $\begin{array}{c}0.15- \\
0.29\end{array}$ & $\mathrm{BA}$ & $\begin{array}{l}\text { Massive that } \\
\text { disrupts in moderate } \\
\text { and firm blocks; few } \\
\text { thin roots; irregular } \\
\text { and diffuse limit. }\end{array}$ & 5YR $3.5 / 4$ & $\begin{array}{l}\text { Reddish brown } \\
\text { to dark reddish } \\
\text { brown }\end{array}$ \\
\hline $\begin{array}{c}0.29- \\
0.65\end{array}$ & $\mathrm{Bi}$ & $\begin{array}{l}\text { Large macro } \\
\text { prismatic structure } \\
\text { that breaks in } \\
\text { subangular large, } \\
\text { moderate and firm } \\
\text { blocks; frequent and } \\
\text { oblique (N60W/ } \\
\text { 35SE) roots; } \\
\text { irregular and diffuse } \\
\text { limit. }\end{array}$ & $5 Y R 4 / 6$ & Yellowish red \\
\hline $\begin{array}{c}0.65- \\
0.79\end{array}$ & 2Bicn & $\begin{array}{l}\text { Very weak block } \\
\text { structure that } \\
\text { disrupts in very thin } \\
\text { grains, very friable; } \\
\text { few roots (horizontal } \\
\text { and oblique); } \\
\text { presence of goethite } \\
\text { and hematite } \\
\text { concretions; result } \\
\text { from desintegration } \\
\text { of ferruginous } \\
\text { laterites wormlike; } \\
\text { irregular and diffuse } \\
\text { limit. }\end{array}$ & $5 Y R 4 / 6$ & Yellowish red \\
\hline $\begin{array}{c}0.79- \\
0.93\end{array}$ & 3Bicn2 & $\begin{array}{l}\text { Laterite remains in } \\
\text { decomposition } \\
\text { passing to goethites } \\
(20 \%) \text { and green ( } 5 \mathrm{Y} \\
7 / 8) \text { gleyzation } \\
(10 \%) \text {, and with } \\
\text { hematite remains } \\
(25 \%) \text {; large and } \\
\text { weak block structure } \\
\text { that disrupts in very }\end{array}$ & $\begin{array}{l}7.5 \text { YR } 4 / 4 \\
10 Y R 5 / 8\end{array}$ & $\begin{array}{l}\text { Brown to } \\
\text { reddish brown }\end{array}$ \\
\hline
\end{tabular}


Table 1 (continued)

\begin{tabular}{|c|c|c|c|c|}
\hline $\begin{array}{l}\text { Depth } \\
\text { (m) }\end{array}$ & Horizon & Description & $\begin{array}{l}\text { Munsell } \\
\text { (1994) } \\
\text { code }\end{array}$ & Color \\
\hline $\begin{array}{c}0.93- \\
1.10\end{array}$ & Fm-G & $\begin{array}{l}\text { small, weak, and } \\
\text { friable grains; } \\
\text { irregular and clear } \\
\text { limit. } \\
\text { Intense wavy } \\
\text { formation of } 0.5 \mathrm{~cm}- \\
\text { thick goethite and } \\
\text { hematite; irregular } \\
\text { and clear limit. }\end{array}$ & $2.5 \mathrm{YR} 7 / 8$ & Yellow \\
\hline $\begin{array}{c}1.10- \\
1.24\end{array}$ & $4 \mathrm{Fm}-\mathrm{H}_{2}$ & $\begin{array}{l}\text { Laterite cemented } \\
\text { by hematite with } \\
\text { ferrolysis in } \\
\text { approximately } 10 \% \\
\text { of the weight. }\end{array}$ & $\begin{array}{l}2.5 \mathrm{YR} 4 / 8 \\
2.5 \mathrm{Y} 7 / 8 \\
2.5 \mathrm{YR} \\
2.5 / 2\end{array}$ & Yellow \\
\hline $1.50(?)$ & Crf (PL-01) & $\begin{array}{l}\text { Plintite from } \\
\text { sandstone of } \\
\text { Pirambóia } \\
\text { Formation. }\end{array}$ & $\begin{array}{l}\text { 5YR 5/6 } \\
5 \text { YR 4/6 }\end{array}$ & $\begin{array}{l}\text { Red, yellow, } \\
\text { brownish red }\end{array}$ \\
\hline $1.60(?)$ & $\operatorname{Crf}(\mathrm{PL}-02)$ & $\begin{array}{l}\text { Plintite from } \\
\text { sandstone of } \\
\text { Pirambóia }\end{array}$ & $\begin{array}{l}\text { 5YR 5/6 } \\
5 Y R ~ 4 / 6\end{array}$ & $\begin{array}{l}\text { Red, yellow, } \\
\text { brownish red }\end{array}$ \\
\hline outcrop & $\mathrm{R}$ & $\begin{array}{l}\text { Formation. } \\
\text { Sandstone from } \\
\text { Pirambóia } \\
\text { Formation with } \\
\text { S20E/35SW } \\
\text { fractures. }\end{array}$ & & \\
\hline
\end{tabular}

constituents and titanium/phosphorus. $\mathrm{TiO}_{2}$ correlated directly with $\mathrm{SiO}_{2}$ and inversely with $\mathrm{Fe}_{2} \mathrm{O}_{3}$, whereas the opposite happened with $\mathrm{P}_{2} \mathrm{O}_{5}$ (Fig. 4).

LOI expresses $\mathrm{OM}+$ adsorbed water+water in crystal lattices and fluid inclusions $+\mathrm{CO}_{2}$ of carbonates $+\mathrm{SO}_{2}$ of sulfides (Faure, 1991). Table 2 shows that the LOI values in the horizons of the soil profile 2 are between $8.9 \%$ and $12.7 \%$, exceeding the OM range from $1.2-3.6 \%$, as expected from the LOI definition. Because LOI is a parameter associated with $\mathrm{OM}$, sometimes there is a significant relationship between them like verified by Bonotto and Vergotti (2015) in sediments profiles of Rondonian lakes. However, such a trend was not found in soil profile 2.

$\mathrm{OM}$ also influences the specific surface area $\left(\mathrm{m}^{2} / \mathrm{g}\right)$ of soils/ sediments as $1 \% \mathrm{OM}$ in porous matrices provides an increase of $\sim 7 \mathrm{~m}^{2}$ into their surface area (Kiehl, 1977). The $\mathrm{SiO}_{2}$ content decreased in accordance with the OM increase in several sediments profiles of the hydrographic basins reported by Bonotto and García-Tenorio (2014) that is compatible with an increment in the sediments surface area. However, a similar finding was not identified in soil profile 2 as the $\mathrm{SiO}_{2}$ content increased according to the $\mathrm{OM}$ increase, whereas an opposite trend was found between $\mathrm{Fe}_{2} \mathrm{O}_{3}$ and OM (Fig. 4).

\subsection{Uranium concentration in the horizons of the soil profiles}

Iron oxides have been shown to play an important role in the retention of uranium and such property has been extensively used for several purposes like the storage and disposal of spent nuclear fuels (e.g. Dodge et al., 2002; Stubbs et al., 2006; Romero-González et al., 2007; Marshall et al., 2014) or U-removal from groundwater (e.g. Bonotto and Andrews, 1993; Bonotto, 2006, 2013, 2016). Immobilization of $\mathrm{U}(\mathrm{VI})$ by incorporation into hematite has clear and important implications for limiting uranium migration in natural and engineered environments (Marshall et al., 2014). The quantitative coprecipitation of uranium occurs with 2-line ferrihydrite (Bruno et al., 1995) and it has been demonstrated that the occurrence of uranium adsorption onto sand coated with synthetic goethite is accompanied by the release of protons from low- and high-affinity binding sites (Gabriel et al., 1998), and also that goethite, hematite, and ferrihydrite present on the surfaces of iron nodules scavenged uranium from groundwater downgradient of a uranium ore deposit (Sato et al., 1997).

In this research, the importance of iron oxides on the uranium retention were evidenced by the inverse relationships between silica
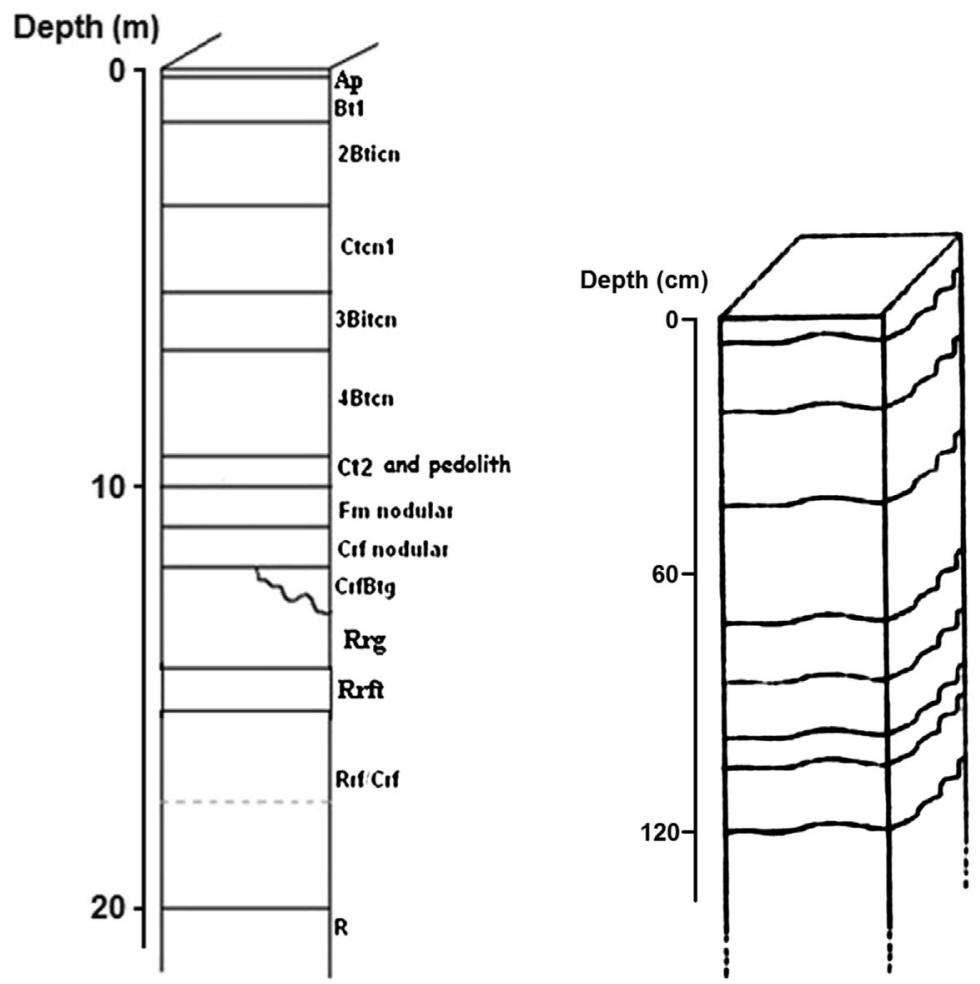

Ap

$A B$

BA

$\mathrm{Bi}$

2Bion

3Bicn2

Fm-G

$4 \mathrm{Fm}-\mathrm{H}_{2}$

Fig. 2. Soil profile 1 (Piracicaba city - left) and soil profile 2 (Rio Claro city - right) sampled at São Paulo State, Brazil. 
Table 2

Chemical analyses of the two soil profiles sampled at São Paulo State, Brazil.

\begin{tabular}{|c|c|c|c|c|c|c|c|c|c|c|c|c|c|c|}
\hline Horizon & $\mathrm{SiO}_{2}(\%)$ & $\mathrm{Na}_{2} \mathrm{O}(\%)$ & $\mathrm{K}_{2} \mathrm{O}(\%)$ & $\mathrm{CaO}(\%)$ & $\mathrm{MgO}(\%)$ & $\mathrm{Al}_{2} \mathrm{O}_{3}(\%)$ & $\mathrm{P}_{2} \mathrm{O}_{5}(\%)$ & $\mathrm{Fe}_{2} \mathrm{O}_{3}(\%)$ & $\mathrm{MnO}(\%)$ & $\mathrm{TiO}_{2}(\%)$ & $\mathrm{LOI}^{\mathrm{a}}(\%)$ & $\mathrm{OM}^{\mathrm{b}}(\%)$ & $\begin{array}{l}\Sigma \text { Bases }^{\mathrm{c}} \\
\mathrm{mmol} / \\
100 \mathrm{~g} \mathrm{( \% )}\end{array}$ & $\begin{array}{l}\Sigma \mathrm{R}_{2} \mathrm{O}_{3}{ }^{\mathrm{d}} \\
\mathrm{mmol} / \\
100 \mathrm{~g}(\%)\end{array}$ \\
\hline \multicolumn{15}{|c|}{ Soil Profile 1 - Piracicaba city } \\
\hline $\mathrm{Bt}_{1}$ & 55.32 & 0.07 & 0.05 & 0.04 & 0.03 & 19.11 & 0.05 & 12.99 & 0.05 & 2.22 & nc & 2.59 & nc & nc \\
\hline 2Bticn & 55.77 & 0.07 & 0.05 & 0.03 & 0.06 & 19.59 & 0.06 & 12.67 & 0.05 & 2.26 & nc & 1.98 & nc & nc \\
\hline $\mathrm{Ctcn}_{1}$ & 55.88 & 0.07 & 0.04 & 0.03 & 0.05 & 19.55 & 0.06 & 12.89 & 0.05 & 2.29 & nc & 1.66 & nc & nc \\
\hline 3Bitcn & 56.54 & 0.07 & 0.05 & 0.04 & 0.05 & 19.89 & 0.05 & 13.15 & 0.05 & 2.38 & nc & 1.52 & nc & nc \\
\hline 4Bten & 56.71 & 0.07 & 0.05 & 0.05 & 0.03 & 19.36 & 0.05 & 13.08 & 0.05 & 2.27 & nc & 0.9 & nc & $\mathrm{nc}$ \\
\hline $\mathrm{Ct}_{2}$ & 56.62 & 0.07 & 0.05 & 0.04 & 0.03 & 19.50 & 0.05 & 12.68 & 0.05 & 2.36 & nc & 1.28 & nc & $\mathrm{nc}$ \\
\hline Pedolith & 57.65 & 0.07 & 0.05 & 0.04 & 0.02 & 19.58 & 0.05 & 11.90 & 0.05 & 2.42 & nc & 0.85 & nc & nc \\
\hline Fm nodular & 39.44 & 0.05 & 0.67 & 0.03 & 0.27 & 16.54 & 0.14 & 32.11 & 0.02 & 1.74 & $\mathrm{nc}$ & 1.84 & nc & nc \\
\hline Crf nodular & 26.20 & 0.02 & 0.16 & 0.04 & 0.11 & 14.63 & 0.27 & 46.26 & 0.01 & 1.23 & $\mathrm{nc}$ & 1.39 & nc & nc \\
\hline $\operatorname{Rrg}$ & 70.89 & 0.08 & 0.78 & 0.04 & 0.26 & 13.90 & 0.14 & 6.70 & 0.01 & 1.24 & nc & 1.54 & nc & $\mathrm{nc}$ \\
\hline CrfBtg & 50.05 & 0.08 & 1.55 & 0.03 & 0.65 & 23.92 & 0.10 & 12.69 & 0.05 & 1.44 & $\mathrm{nc}$ & 1.72 & nc & nc \\
\hline Rrft & 69.53 & 0.08 & 1.13 & 0.04 & 0.39 & 14.31 & 0.14 & 7.46 & 0.01 & 0.98 & nc & 1.12 & nc & $\mathrm{nc}$ \\
\hline Crf & 71.79 & 0.09 & 1.09 & 0.04 & 0.37 & 17.06 & 0.04 & 2.25 & 0.01 & 0.91 & nc & 1.16 & nc & $\mathrm{nc}$ \\
\hline Rrf & 81.77 & 0.08 & 0.46 & 0.05 & 0.15 & 6.68 & 0.36 & 6.15 & 0.01 & 0.66 & nc & 1.53 & nc & nc \\
\hline $\mathrm{R}$ & 88.04 & 0.13 & 1.12 & 0.07 & 0.40 & 6.74 & 0.02 & 0.61 & 0.01 & 0.37 & $\mathrm{nc}$ & 1.45 & nc & nc \\
\hline \multicolumn{15}{|c|}{ Soil Profile 2 - Rio Claro city } \\
\hline $\mathrm{AB}$ & 65.99 & 0.04 & 0.03 & 0.03 & 0.06 & 12.47 & 0.06 & 9.70 & 0.03 & 2.69 & 8.9 & 2.87 & 0.16 & 11.95 \\
\hline BA & 68.22 & 0.05 & 0.03 & 0.03 & 0.05 & 11.18 & 0.05 & 8.51 & 0.02 & 2.47 & 9.39 & 2.75 & 0.16 & 10.46 \\
\hline $\mathrm{Bi}$ & 63.61 & 0.05 & 0.03 & 0.03 & 0.07 & 11.82 & 0.05 & 9.00 & 0.02 & 2.58 & 12.74 & 2.54 & 0.17 & 10.36 \\
\hline 2Bicn & 56.70 & 0.04 & 0.03 & 0.04 & 0.07 & 12.73 & 0.06 & 17.10 & 0.03 & 2.60 & 10.59 & 3.58 & 0.19 & 14.69 \\
\hline 3Bicn2 & 55.55 & 0.04 & 0.04 & 0.04 & 0.09 & 12.06 & 0.05 & 17.86 & 0.02 & 2.60 & 11.65 & 1.48 & 0.22 & 14.29 \\
\hline Fm-G & 31.92 & 0.03 & 0.04 & 0.03 & 0.07 & 14.18 & 0.09 & 41.11 & 0.01 & 2.02 & 10.23 & 1.17 & 0.21 & 27.67 \\
\hline $4 \mathrm{Fm}-\mathrm{H}_{2}$ & 31.92 & 0.04 & 0.03 & 0.03 & 0.06 & 10.92 & 0.07 & 42.80 & 0.02 & 1.89 & 12.22 & 1.38 & 0.19 & 24.74 \\
\hline Crf (PL-01) & 83.73 & 0.13 & 0.05 & 0.04 & 0.10 & 9.13 & 0.02 & 2.19 & $<0.01$ & 0.48 & 4.14 & $\mathrm{nc}$ & 0.33 & 6.28 \\
\hline Crf (PL-02) & 84.72 & 0.11 & 0.06 & 0.04 & 0.08 & 8.52 & 0.02 & 1.71 & $<0.01$ & 0.52 & 4.21 & $\mathrm{nc}$ & 0.29 & 5.76 \\
\hline $\mathrm{R}$ & 91.15 & 0.25 & 0.74 & 0.07 & 0.08 & 5.29 & 0.02 & 0.54 & 0.01 & 0.05 & 1.81 & nc & 0.90 & 3.31 \\
\hline
\end{tabular}

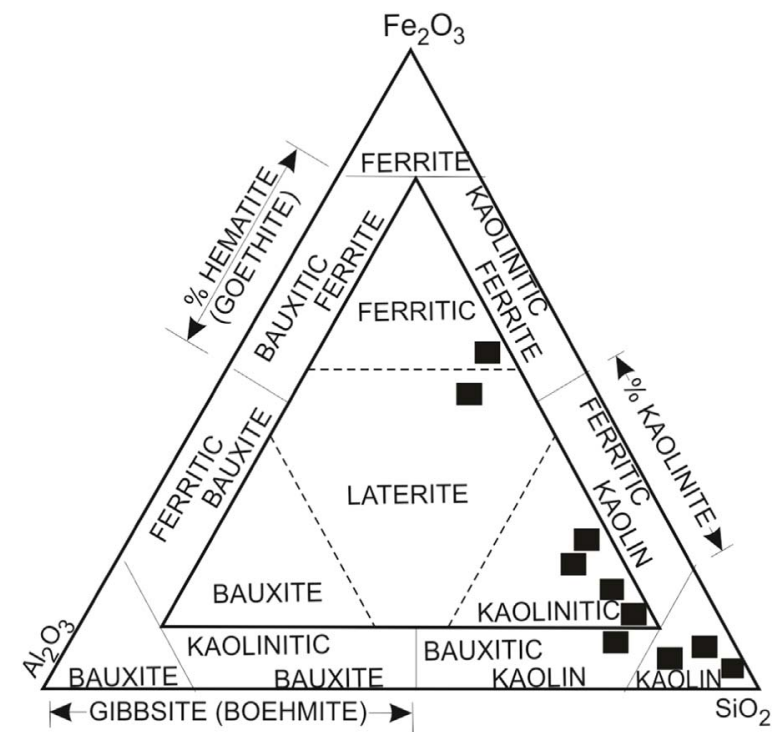

Fig. 3. Data for the analyzed samples of soil profile 2 plotted on the $\mathrm{SiO}_{2}-\mathrm{Al}_{2} \mathrm{O}_{3}-\mathrm{Fe}_{2} \mathrm{O}_{3}$ diagram proposed by Balasubramaniam et al. (1983).

and iron as plotted in Fig. 4. They implied on other significant relationships affecting the uranium distribution along the horizons of both soil profiles due to the processes occurring there. The uranium concentration increased according to the $\mathrm{Fe}_{2} \mathrm{O}_{3}$ increase in both soil profiles as shown in Fig. 5, whereas an opposite trend was found between the uranium and $\mathrm{SiO}_{2}$ concentrations.

Szalay (1964) pointed out the OM importance on the uranium adsorption, considering that the accumulation of this element occurs after the plants decomposition, whose lignin partially transforms in insoluble humic acids during the humification process. The experiments of Szalay (1964) indicated that the adsorption mechanism in which the humic acids concentrate the uranium dissolved in natural waters is a cation exchange process. Pauli (1975) performed laboratory experiments with a material derived from weathered lignin in order to study the mechanisms involved as it exhibited adequate properties for adsorption of heavy metals. Humic complexes of $\mathrm{UO}_{2}{ }^{2+}, \mathrm{Pb}, \mathrm{Cu}, \mathrm{Zn}, \mathrm{Ni}$ and $\mathrm{Cd}$ were obtained on adding different amounts of powdered materials to the humus suspension of variable concentration. The results indicated that the uranyl ion $\left(\mathrm{UO}_{2}{ }^{2+}\right)$ combines with the humic compound utilized in a more accentuated proportion and much faster than the other metallic ions (Pauli, 1975). Despite these and other findings, non-significant correlation was found between the uranium and $\mathrm{OM}$ concentrations in the horizons of profile 1 , whereas an inverse relationship was determined in the soil profile 2 (Fig. 5) that is related to the opposite $\mathrm{OM}$ trends with $\mathrm{SiO}_{2}$ and $\mathrm{Fe}_{2} \mathrm{O}_{3}$ as shown in Fig. 4.

A deep understanding of the opposite relationships involving $\mathrm{OM}$, $\mathrm{SiO}_{2}$ and $\mathrm{Fe}_{2} \mathrm{O}_{3}$ in the soil profile 2 is beyond the scope of this paper as it has been recognized, for instance, that ferrihydrite is an yet enigmatic nano Fe(III)-oxide material, which, although extensively studied, to date no proper view exists on its surface structure and composition (Hiemstra, 2013). Because of its vital importance to our understanding of ion complexation in terrestrial and aquatic systems, the surface structure of ferrihydrite was investigated by Hiemstra (2013) in relation to that of the mineral core, showing a unique surface composition differing from the mineral core. Additionally, the results reported by Marshall et al. (2014) both provided a new mechanistic understanding of uranium incorporation into hematite and defined the nature of the bonding environment of uranium within the mineral structure.

Surface complexation modeling has been used to describe/predict 

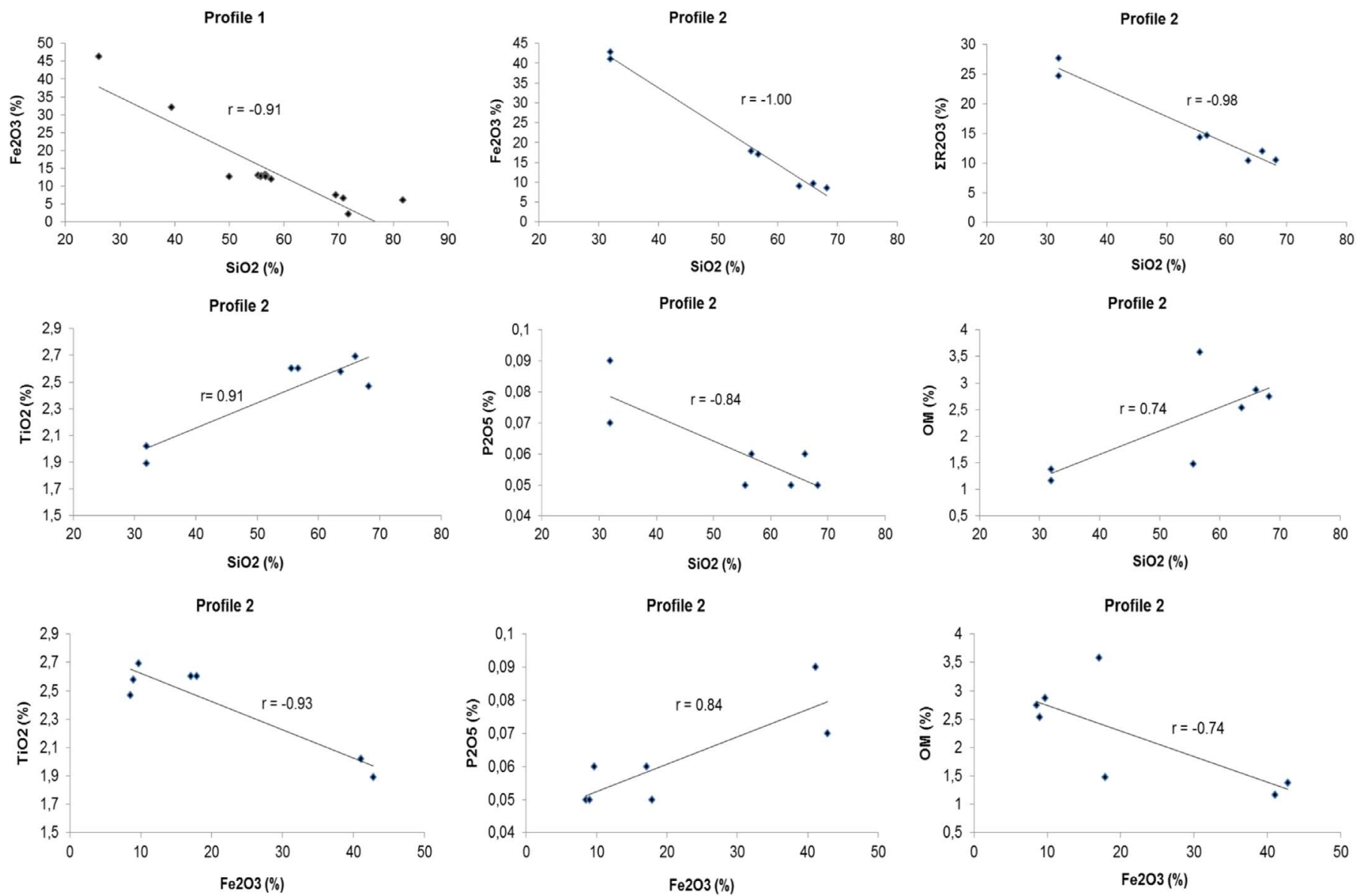

Fig. 4. The relationships involving $\mathrm{SiO}_{2}, \mathrm{Fe}_{2} \mathrm{O}_{3}, \mathrm{R}_{2} \mathrm{O}_{3}, \mathrm{TiO}_{2}, \mathrm{P}_{2} \mathrm{O}_{5}$ and organic matter (OM) in the soil profiles investigated in this paper.

metal and radionuclide adsorption onto different geological materials, for instance, Waite et al. (1994) used it to describe U(VI) adsorption on pure hydrous ferric oxide over a range of $\mathrm{pH}, \mathrm{U}(\mathrm{VI})$ concentrations, and $\mathrm{CO}_{2(\mathrm{~g})}$ partial pressures, whereas Nilsson et al. $(1992,1996)$ reported the adsorption of phosphate as a single adsorbate and as a competitive adsorbate onto oxides surface. Romero-González et al. (2007) reported that the phosphate adsorption exhibits a stronger dependence on Fe(III) oxide type than U(VI) adsorption, incorporating the effects of phosphate on U(VI) adsorption into a model to describe $\mathrm{U}(\mathrm{VI})$ adsorption to both amorphous and crystalline Fe(III) oxides and goethite-coated sand. Such findings are good indicators for explaining the significant relationships found among the concentrations of uranium, $\mathrm{P}_{2} \mathrm{O}_{5}$, and $\mathrm{Fe}_{2} \mathrm{O}_{3}$ in the horizons of soil profile 2 (Fig. 5).

The uranium distribution along the horizons of both soil profiles studied in this research is different to that verified by Bonotto and Jiménez-Rueda (2007) in the soil profile developed over the Itararé Subgroup (also in the Paraná basin) and located at Limeira municipality, about $20 \mathrm{~km}$ distant from Rio Claro and Piracicaba cities. Bonotto and Jiménez-Rueda (2007) reported that uranium neither accumulated in the soil horizons associated with $\mathrm{Al}_{2} \mathrm{O}_{3}, \mathrm{MgO}, \mathrm{P}_{2} \mathrm{O}_{5}$, $\mathrm{Fe}_{2} \mathrm{O}_{3}, \mathrm{MnO}$, and $\mathrm{TiO}_{2}$ nor correlated with $\mathrm{OM}$ that tended to decrease with increasing depth in the soil horizons. The $\mathrm{U}$ content decreased with increasing $\mathrm{K}_{2} \mathrm{O}$ content and amount of clays, but increased with the amount of sand, that raised towards the more superficial soil horizons, indicating its presence in resistates/minor refractory minerals (zircon) highly resistant to weathering.

\subsection{Soil horizons formation from the ${ }^{234} U /{ }^{238} U$ activity ratios}

Several horizons of the soils profiles exhibit ARs corresponding to unity, within experimental errors, indicating radioactive equilibrium between ${ }^{234} \mathrm{U}$ and ${ }^{238} \mathrm{U}$ in the detritic matrix at least over the last $1 \mathrm{Ma}$ (Latham and Schwarcz, 1987). Thus, there is no occurrence at these sites of extra ${ }^{234} \mathrm{U}$-loss or ${ }^{234} \mathrm{U}$-gain either due to enhanced chemical solution of ${ }^{234} \mathrm{U}$ due to radiation damage to crystal lattices or to autoxidation from $\mathrm{U}^{4+}$ to $\mathrm{U}^{6+}$ resulting from the decay of the parent ${ }^{238} \mathrm{U}$ (Rosholt et al., 1963; Fleischer, 1975) or by $\alpha$-recoil effects (Kigoshi, 1971).

However, ${ }^{234} \mathrm{U}$ has been preferentially accumulated in some soil horizons, generating ARs $>1$, within experimental errors, a typical result related to the effect of rock/soil-water interactions (Osmond and Cowart, 1976). These samples are located in different horizons of the soil profiles, providing useful timing information concerning their formation. These disequilibria allow an estimate of "apparent time" representing the state of disequilibrium acted against by the decay back tending to equilibrium of the shorter-lived daughter ${ }^{234} \mathrm{U}$. This time $(t)$ may be calculated from the initial ${ }^{234} \mathrm{U}$-excess compared to the final ${ }^{234} \mathrm{U}$ equilibrium value (or close to it) according to the following equation (Latham and Schwarcz, 1987; Ivanovich and Harmon, 1992):

$t=-1 / \lambda \ln \left(A R_{f} / A R_{i}\right)$

where: $\lambda$ is the ${ }^{234} \mathrm{U}$ decay constant, $A R_{f}$ is the final (equilibrium or close to it) ${ }^{234} \mathrm{U} /{ }^{238} \mathrm{U}$ activity ratio, and $A R_{i}$ is the initial ( ${ }^{234} \mathrm{U}$-excess) ${ }^{234} \mathrm{U} /{ }^{238} \mathrm{U}$ activity ratio.

Therefore, ${ }^{234} \mathrm{U} /{ }^{238} \mathrm{U}$ activity ratios in Table 3 exceeding unity within the experimental uncertainties were used for applying Eq. (5). It also took into account the direction of the soils horizons formation/ development that is from the deeper portions of the profiles (rock matrices) towards the more superficial covers. The timing information was generated considering two successive layers, but only when the deeper $\left(A R_{i}\right)$ exhibited a higher ${ }^{234} \mathrm{U} /{ }^{238} \mathrm{U}$ activity ratio relative to the shallower $\left(A R_{f}\right)$ immediately above. Thus, it was possible to obtain the 


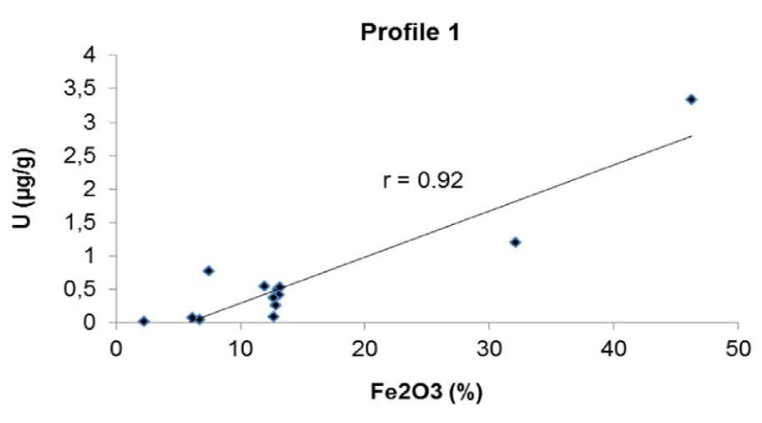

Profile 1
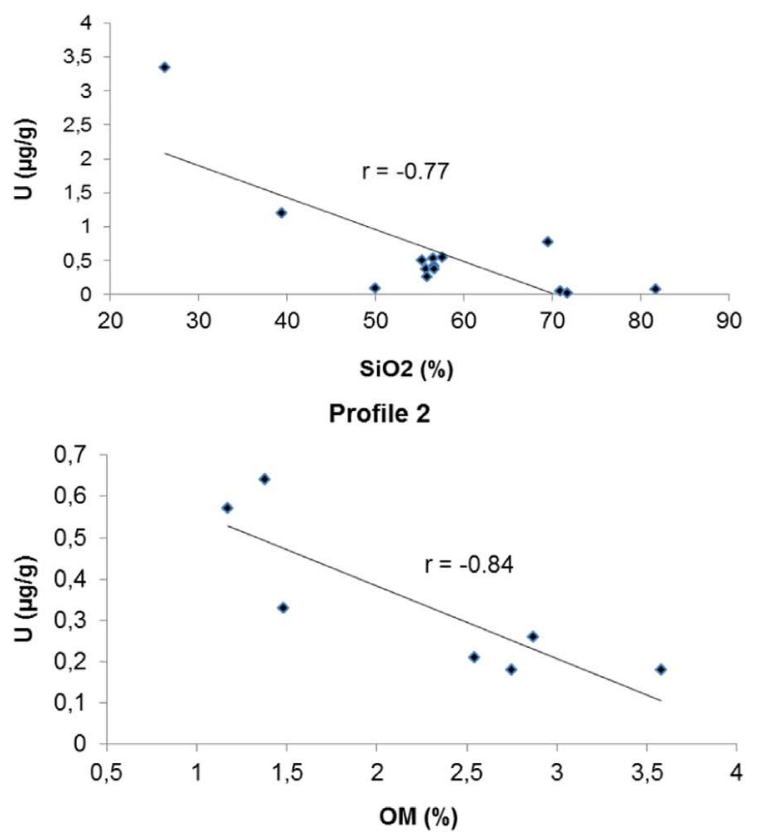

Profile 2

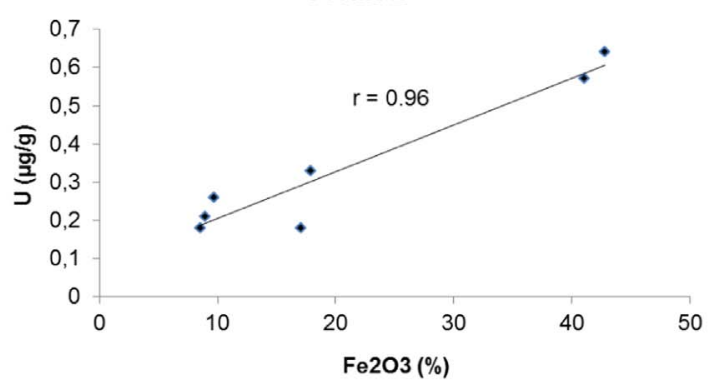

Profile 2

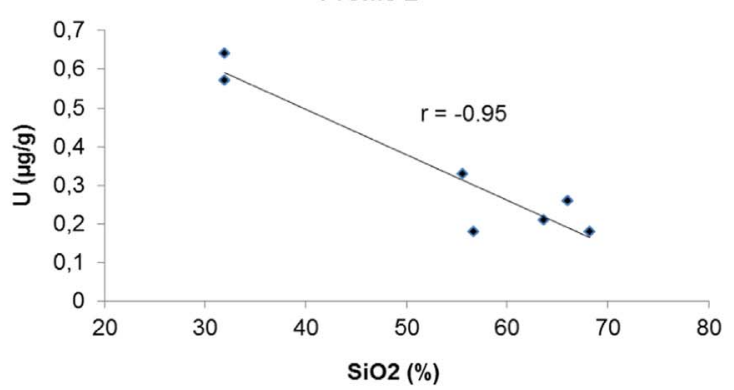

Profile 2

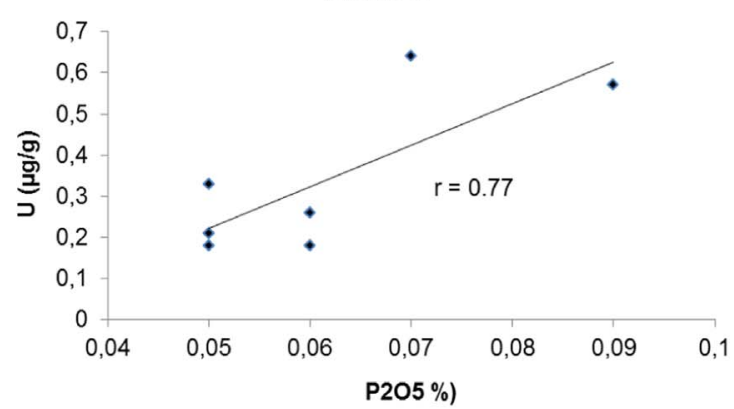

Fig. 5. The relationships involving uranium, $\mathrm{SiO}_{2}, \mathrm{Fe}_{2} \mathrm{O}_{3}, \mathrm{P}_{2} \mathrm{O}_{5}$ and organic matter $(\mathrm{OM})$ in the soil profiles investigated in this paper.

range of 33-408 ka (soil profile 1) and 19-85 ka (soil profile 2) as shown in Table 3. It corresponds to the time for ${ }^{234} \mathrm{U}$ decaying back to equilibrium (or close to it), which may represent the elapsed time for developing the different soil horizons during weathering of the sandstone parent rocks.

The data in Table 3 suggest that different deposition/formation cycles may be related to the studied soil profiles. Thus, profile 1 can be divided according to two different evolution processes from which the oldest covers the horizons from "R" to "Fm nodular" with the inclusion of the "Rrg" horizon as it is a material that suffered recent reduction (gleyzation). The total time elapsed for the development of these horizons corresponds to about $700 \mathrm{ka}$ that is positioned in the Ionian (Middle) Pleistocene (781-126 ka, according to ICS, 2010). Ferreira (2005) dated a soil sample collected in SP-191 highway close to Passa Cinco River by the thermoluminescence technique, obtaining an age of $745 \pm 78 \mathrm{ka}$, also positioned in the same epoch (ICS, 2010). The most

Table 3

U-isotopes data and ages estimated for developing horizons in the two soil profiles sampled at São Paulo State, Brazil.

\begin{tabular}{|c|c|c|c|c|c|c|c|}
\hline \multicolumn{4}{|c|}{ Soil Profile 1 - Piracicaba city } & \multicolumn{4}{|c|}{ Soil Profile 2 - Rio Claro city } \\
\hline Horizon & $\mathrm{U}(\mu \mathrm{g} / \mathrm{g})$ & ${ }^{234} \mathrm{U} /{ }^{238} \mathrm{U}$ A.R. & Time (ka) & Horizon & $\mathrm{U}(\mu \mathrm{g} / \mathrm{g})$ & ${ }^{234} \mathrm{U} /{ }^{238} \mathrm{U}$ A.R. & Time (ka) \\
\hline $\mathrm{Bt}_{1}$ & $0.50 \pm 0.07$ & $0.99 \pm 0.18$ & 65.8 & $\mathrm{AB}$ & $0.26 \pm 0.03$ & $1.05 \pm 0.06$ & 84.6 \\
\hline 2Bticn & $0.37 \pm 0.06$ & $1.19 \pm 0.16$ & 251.0 & BA & $0.18 \pm 0.02$ & $1.33 \pm 0.20$ & \\
\hline $\mathrm{Ctcn}_{1}$ & $0.26 \pm 0.05$ & $2.40 \pm 0.36$ & & $\mathrm{Bi}$ & $0.21 \pm 0.02$ & $1.13 \pm 0.07$ & 24.5 \\
\hline 3Bitcn & $0.53 \pm 0.07$ & $1.40 \pm 0.18$ & & 2Bicn & $0.18 \pm 0.02$ & $1.21 \pm 0.09$ & 41.8 \\
\hline 4Bten & $0.42 \pm 0.06$ & $1.36 \pm 0.23$ & & 3Bicn2 & $0.33 \pm 0.03$ & $1.36 \pm 0.14$ & \\
\hline $\mathrm{Ct}_{2}$ & $0.37 \pm 0.06$ & $1.32 \pm 0.11$ & & Fm-G & $0.57 \pm 0.06$ & $1.09 \pm 0.14$ & 19.2 \\
\hline Pedolith & $0.54 \pm 0.07$ & $1.18 \pm 0.10$ & & $4 \mathrm{Fm}-\mathrm{H}_{2}$ & $0.64 \pm 0.06$ & $1.15 \pm 0.09$ & \\
\hline Fm nodular & $1.20 \pm 0.11$ & $1.08 \pm 0.19$ & & Crf (PL-01) & $<0.03$ & nc & \\
\hline Crf nodular & $3.34 \pm 0.18$ & $0.80 \pm 0.06$ & 407.7 & Crf (PL-02) & $<0.03$ & $\mathrm{nc}$ & \\
\hline $\operatorname{Rrg}$ & $0.05 \pm 0.02$ & $2.50 \pm 0.67$ & 32.8 & $\mathrm{R}$ & $<0.02$ & $\mathrm{nc}$ & \\
\hline CrfBtg & $0.09 \pm 0.03$ & $2.74 \pm 0.60$ & & & & & \\
\hline Rrft & $0.77 \pm 0.03$ & $1.48 \pm 0.06$ & 254.0 & & & & \\
\hline Crf & $0.02 \pm 0.01$ & $3.01 \pm 1.00$ & & & & & \\
\hline Rrf & $0.07 \pm 0.03$ & $2.52 \pm 0.91$ & & & & & \\
\hline $\mathrm{R}$ & $0.14 \pm 0.04$ & $2.03 \pm 0.42$ & & & & & \\
\hline
\end{tabular}

Analytical uncertainty corresponding to $1 \sigma$ standard deviation. 
superficial horizons (from Ct2 and Pedoliths to Bt1) would have youngest development characterized by a time close to $70 \mathrm{ka}$ in the top, corresponding to the Upper Pleistocene (126-11.7 ka, according to ICS, 2010).

Different phases were also noted in soil profile 2 as it is characterized by latosols decomposition/formation in a typical tropical region, residual deposition/formation of horizons resulting from mild favorable climate conditions, organic matter addition $\left(2 \mathrm{Bi}_{\mathrm{cn}}\right)$ and superficial horizons deposition/formation ( $\mathrm{AB}, \mathrm{BA}$ and $\mathrm{Bi}$ ), exhibiting a tendency to the loss of bases by leaching processes. The total time elapsed for the horizons development corresponded to a minimum of $170 \mathrm{ka}$ that is positioned in the Middle Pleistocene (ICS, 2010). Longer times up to about $300 \mathrm{ka}$ could be estimated for the formation of all horizons in profile 2 under the adoption of similar times obtained for Fm-G (to $4 \mathrm{Fm}-\mathrm{H} 2, \sim 19 \mathrm{ka}$ ), $2 \mathrm{Bi}_{\text {cn }}$ (to $3 \mathrm{Bicn} 2, \sim 42 \mathrm{ka}$ ) and $\mathrm{AB}$ (to $\mathrm{BA}, \sim 85 \mathrm{ka}$ ) (Table 3). This time period is positioned in the Middle Pleistocene (ICS, 2010), being equivalent to Paraguaçu erosion cycle (Pleistocene: 2588$11.7 \mathrm{ka}$ ) as pointed out by King (1956).

The extreme ${ }^{234} \mathrm{U} /{ }^{238} \mathrm{U}$ disequilibria values of $0.8-0.9$ in the soil profile developed over the Itararé Subgroup (Paraná basin) allowed Bonotto and Jiménez-Rueda (2007) calculate an "apparent time" of 410-660 ka, representing the elapsed time for developing the more superficial (Bo1, Bo2, and Bo3) soil horizons during weathering of the sandstone parent rock. Such age is also positioned in the Middle Pleistocene as verified in both soil profiles investigated in this research.

\section{Conclusion}

This investigation was realized in the Brazilian part of the Paraná sedimentary basin, South America, comprising the almost central portion of São Paulo State at the cities of Piracicaba and Rio Claro. The major chemical composition and radioactivity due to uranium isotopes ${ }^{238} \mathrm{U}$ and ${ }^{234} \mathrm{U}$ in horizons of two soil profiles were determined with the aim of evaluating the weathering processes and estimating the formation age through the U-isotopes disequilibrium technique. Silica was the major oxide of practically all horizons of both soil profiles, except in some cases where $\mathrm{Fe}_{2} \mathrm{O}_{3}$ was dominant. Silica and iron correlated inversely in both soil profiles that implied on other significant relationships affecting the uranium distribution along the horizons due to the processes occurring there. The uranium concentration increased according to the $\mathrm{Fe}_{2} \mathrm{O}_{3}$ increase in both soil profiles, whereas it was identified as an opposite trend between the uranium and $\mathrm{SiO}_{2}$ concentrations. The U-isotopes data were favorable to apply the available models for estimating the elapsed time for developing the soil horizons during weathering of the sandstone parent rocks occurring in Paraná sedimentary basin. The ${ }^{238} \mathrm{U}$ and ${ }^{234} \mathrm{U}$ disequilibria data allowed an estimate of "apparent ages" representing the state of disequilibrium acted against by the trend to decay back to equilibrium of the shorter-lived daughter ${ }^{234} \mathrm{U}$. Such time was calculated from the initial higher ${ }^{234} \mathrm{U}$-excess compared to the final lower ${ }^{234} \mathrm{U}$ value, yielding ages positioned in the Middle Pleistocene (781-126 ka) that were compatible with others from previous studies. For instance, a maximum kaolinization age of $280 \mathrm{Ma}$ was reported in Cornwall, UK, which affected not only granite but also felsic dykes that cut across the quartz veins. This indicated initially the occurrence of a hydrothermal kaolinization process that was later affected by supergene processes. Thus, the hydrothermal kaolinization was overprinted possibly in the Tertiary by weathering and leaching of iron, agreeing with the findings of this paper. The wet conditions (non-glacial climate) over the time period corresponding to the Middle Pleistocene were also evidenced by the presence of plintites in the soil profiles investigated.

\section{Acknowledgments}

CNPq (National Council for Scientific and Technologic Development) in Brazil is greatly thanked for financial support of scholarships to I.C.F. and C.R.A.F.F. One anonymous reviewer is greatly thanked for helpful comments that improved the readability of the manuscript.

\section{References}

Balasubramaniam, K.S., Moorthy, V.K., Vyas, B.R., 1983. Significance of engineering properties in understanding the proper utilization of laterites from western India. Proc. Int. Semin. Laterisation Process. II, 577-590.

Bernal, J.P., Eggins, S.M., McCulloch, M.T., Grün, R., Eggleton, R.A., 2006. Dating of chemical weathering processes by in situ measurement of U-series disequilibria in supergene Fe oxy/hydroxides using LAMC-ICP-MS. Chem. Geol. 235, 76-94.

Bonotto, D.M., 2006. Hydro(radio)chemical relationships in the giant Guarani aquifer, Brazil. J. Hydrol. 323, 353-386.

Bonotto, D.M., 2013. A cOmparative Study of Aquifer Systems Occurring at The Paraná Sedimentary Basin, Brazil: U-isotopes ContributionEnviron. Earth Sci 68, 1405-1418.

Bonotto, D.M., Jimenez-Rueda, J.R., 2007. U-ages in soils and groundwater evidencing wet periods 400-600 kyr ago in southeast Brazil. Appl. Radiat. Isot. 65, 776-783.

Bonotto, D.M., Vergotti, M., 2015. ${ }^{210} \mathrm{~Pb}$ and compositional data of sediments from Rondonian lakes, Madeira River basin, Brazil. Appl. Radiat. Isot. 99, 5-19.

Bonotto, D.M., 2016. The dissolved uranium concentration and ${ }^{234} U /{ }^{238} U$ activity ratio in groundwaters from spas of southeastern Brazil. J. Environ. Radioact.. http:// dx.doi.org/10.106/ j.jenvrad.2016.03.009.

Bonotto, D.M., Andrews, J.N., 1993. The mechanism of ${ }^{234} \mathrm{U} /{ }^{238} \mathrm{U}$ activity ratio enhancement in karstic limestone groundwater. Chem. Geol. (Isot. Geosci. Sect.) 103, 193-206.

Bonotto, D.M., García-Tenorio, R., 2014. A comparative evaluation of the CF:CS and CRS models in ${ }^{210} \mathrm{~Pb}$ chronological studies applied to hydrographic basins in Brazil. Appl. Radiat. Isot. 92, 58-72.

Bonotto, D.M., Fujimori, K., Moreira-Nordemann, L.M., 2007. Determination of weathering rate of the Morro do Ferro Th-REEs deposit, Brazil using U-isotope method. Appl. Radiat. Isot. 65, 474-481.

Bruno, J., de Pablo, J., Duro, L., Figuerola, E., 1995. Experimental study and modeling of the U(VI)-Fe(OH) $)_{3}$ surface precipitation/coprecipitation equilibria. Geochim. Cosmochim. Acta 59, 4113-4123.

Chabaux, F., 2010. U-series nuclides in weathering profiles: rates of soil processes. In: Proceedings 19th World Congress of Soil Science, Soil Solutions for a Changing World, Brisbane, pp. 38-41.

Chabaux, F., Dequincey, O., Levesque, J.J., Leprun, J.C., Clauer, N., Riotte, J., Paquet, H., 2003. Tracing and dating recent chemical transfers in weathering profiles by trace element geochemistry and 238U-234U- ${ }^{230} \mathrm{Th}$ disequilibria: the example of the Kaya lateritic toposequence (Burkina-Faso). CR Geosci. 335, 1219-1231.

Chabaux, F., Pelt, E., Lucas, Y., Allard, T., Fritsch, E., Balan, E., Selo, M., 2006. 238U$234 \mathrm{U}-{ }^{230} \mathrm{Th}_{-}{ }^{226} \mathrm{Ra}$ radioactive disequilibria in an Amazon lateritic profile (Manaus, Brazil). Geochim. Cosmochim. Acta 70 (S1), A93.

Chabaux, F., Bourdon, B., Riotte, J., 2008. U-series geochemistry in weathering profiles, river waters and lakes. In: Krishnaswami, S., Cochran, J.K. (Eds.) Radioactivity in the Environment: U-Th Series nuclides in aquatic systems, v. 13, pp. 49-104.

Colman, S.M., 1982. Chemical weathering of basalts and andesites: evidence from weathering rinds. U. S. Geol. Surv. Prof. Pap. 1246, 1-51.

Conceição, F.T., Bonotto, D.M., 2003. Use of U-isotope disequilibrium to evaluate the weathering rate and fertilizer-derived uranium in São Paulo State Brazil. Environ. Geol. 44, 408-418.

Currie, L.A., 1968. Limits for qualitative and quantitative determination. Anal. Chem. 40, 586-593.

Daemon, R.F., Quadros, L.P., 1970. Bioestratigrafia do Neopaleozóico da Bacia do Paraná. In: Proceedings of XXIV Congresso Brasileiro de Geologia, SBG-Sociedade Brasileira de Geologia, Brasília, pp. 359-412.

Dequincey, O., Chabaux, F., Clauer, N., Sigmarsson, O., Liewig, N., Leprun, J.C., 2002. Chemical mobillizations in laterites: evidence from trace elements and 238U234U- ${ }^{230}$ Th disequilibria. Geochim. Cosmochim. Acta 66, 1197-1210.

Dodge, C.J., Francis, A.J., Gillow, J.B., Halada, G.P., Eng, C., Clayton, C.R., 2002. Association of uranium with iron oxides typically formed on corroding steel surfaces. Environ. Sci. Technol. 36, 3504-3511.

Dosseto, A., Turner, S.P., Chappell, J., 2008. The evolution of weathering profiles through time: new insights from uranium-series isotopes. Earth Planet. Sci. Lett. 274, 359-371.

Faure, G., 1991. Principles and Applications of Inorganic Geochemistry. MacMillan Publishing Co., New York, 626.

Federici, P.R., Pappalardo, M., 2001. First finding of a terrace with preserved marine deposit along the coast of Eastern Liguria (Italy). Rend. Fis. Acc. Lince-. 9, 69-82.

Ferreira, S.R., 2005. Análise Pedoestratigráfica Das Formações Rio Claro E Piraçununga, No Centro-leste do estado de São Paulo (Ph.D thesis). UNESP-São Paulo State University, Rio Claro, 157.

Fleischer, R.L., 1975. On the dissolution of respirable $\mathrm{PuO}_{2}$ particles. Health Phys. 29, 69-73.

Fleischer, R.L., Raabe, O.G., 1978a. Recoiling alpha-emitting nuclei-mechanisms for uranium series disequilibrium. Geochim. Cosmochim. Acta 42, 973-978.

Fleischer, R.L., Raabe, O.G., 1978b. On the mechanism of "dissolution" in liquids of $\mathrm{PuO}_{2}$ by alpha decay. Health Phys. 35, 545-548.

Fúlfaro, J.V., Stevaux, J.C., Souza Filho, E.E., Barcelos, J.H., 1984. A Formação Tatuí no estado de São Paulo. In: Proceedings of XXXIII Congresso Brasileiro de Geologia, SBG-Sociedade Brasileira de Geologia, Rio de Janeiro, v. 2, pp. 711-724. 
Gabriel, U., Gaudet, J.-P., Spadini, L., Charlet, L., 1998. Reactive transport of uranyl in a goethite column: an experimental and modelling study. Chem. Geol. 151, 107-128.

Gimenez, N.L.B., 1996. Estudo petrológico dos arenitos da Formação Tatuí no Estado de São Paulo (Ms. dissertation). UNESP-São Paulo State University, Rio Claro, 140.

Hach, 1992. Water Analysis Handbook 2nd ed.. Hach Co., Loveland, 831.

Hansen, R.O., Stout, P.R., 1968. Isotopic distribution of uranium and thorium in soils. Soil Sci. $105,44-50$.

Hiemstra, T., 2013. Surface and mineral structure of ferrihydrite. Geochim. Cosmochim. Acta 105, 316-325.

IBGE (Instituto Brasileiro de Geografia e Estatística), 2007. Manual Técnico de Pedologia. 2nd ed., IBGE-Diretoria de Geociências, Coordenação de Recursos Naturais e Estudos Ambientais, Rio de Janeiro, 316 pp.

ICS (International Comission on Stratigraphy), 2010. International stratigraphic chart. Available online at 〈http://www.stratigraphy.org/upload/ISChart2009.pdf).

IPT (Technological Research Institute of São Paulo State), 1981. Geological Map From São Paulo State: Scale 1:500.000. Monographs, IPT, São Paulo, 94.

Ivanovich, M., Harmon, R.S., 1992. Uranium Series Disequilibrium: Applications to Environmental Problems 2nd ed.. Clarendon Press, Oxford.

Kiehl, E.J., 1977. Interpretation of soil properties. Teaching text, ESALQ (University of Agriculture "Luiz de Queirós". USP-University of São Paulo, Piracicaba, 237.

Kigoshi, K., 1971. Alpha-recoil ${ }^{234}$ Th: dissolution into water and the ${ }^{234} \mathrm{U} /{ }^{238} \mathrm{U}$ disequilibrium in nature. Science 173, 47-48.

King, L.C., 1956. A geomorfologia do Brasil oriental. Rev. Bras. De. Geogr. XVIII 2, 2-265.

Latham, A.G., Schwarcz, H.P., 1987. On the possibility of determining rates of removal of uranium from crystalline igneous rocks using U-series disequilibria-1: a U-leach model, and its applicability to whole-rock data. Appl. Geochem. 2, 55-65.

Marshall, T.A., Morris, K., Law, G.T.W., Livens, F.R., Mosselmans, J.F.W., Bots, P., Shaw, S., 2014. Incorporation of uranium into hematite during crystallization from ferrihydrite. Environ. Sci. Technol. 48, 3724-3731.

Munsell, 1994. Soil Color Charts. Kollmorgen Instruments - Macbeth Division, New Windson.

Nilsson, N., Loevgren, L., Sjoeberg, S., 1992. Phosphate complexation at the surface of goethite. Chem. Spec. Biovailab. 4, 121-130.

Nilsson, N., Persson, P., Loevgren, L., Sjoeberg, S., 1996. Competitive surface complexation of o-phthalate and phosphate on goethite $(\alpha-\mathrm{FeOOH})$ particles. Geochim. Cosmochim. Acta 60, 4385-4395.
Osmond, J.K., Cowart, J.B., 1976. The theory and uses of natural uranium isotopic variations in hydrology. At. Energy Rev. 14, 621-679.

Pauli, F.W., 1975. Heavy metal humates and their behavior against hydrogen sulfide. Soil Sci. 119 (1), 98-105.

Pohl, W.L., 2011. Economic Geology: Principles and Practice. Wiley-Blackwell, Oxford.

Reiche, P., 1943. Graphic representation of chemical weathering. J. Sedim. Res. 13, $58-68$.

Romero-González, M.R., Cheng, T., Barnett, M.O., Roden, E.E., 2007. Surface complexation modeling of the effects of phosphate on uranium (VI) adsorption. Radiochim. Acta 95, 251-259.

Rosholt, J.N., Shields, W.R., Garner, E.L., 1963. Isotope fractionation of uranium in sandstone. Science 139, 224-226.

Rosholt, J.N., Doe, B., Tatsumoto, M., 1966. Evolution of the isotopic composition of uranium and thorium in soil profiles. Geol. Soc. Am. Bull. 77, 987-1004.

Sato, T., Murakami, T., Yanase, N., Isobe, H., Payne, T.E., Airey, P.L., 1997. Iron nodules scavenging uranium from groundwater. Environ. Sci. Technol. 31 (10), 2854-2858.

Schellmann, W., 1979. Considerations on the definition and classification of laterites. In: Proceedings of International Seminar on Laterisation Processes I, 1-10.

Soares, P.C., Landim, P.M.B., 1973. Aspectos regionais da estratigrafia da Bacia do Paraná no seu flanco nordeste. In: Proceedings of XXVII Congresso Brasileiro de Geologia, SBG-Sociedade Brasileira de Geologia, Aracaju, v. 1, pp. 243-256.

Stubbs, J.E., Elbert, D.C., Veblen, D.R., Zhu, C., 2006. Electron microbeam investigation of uranium-contaminated soils from Oak Ridge, TN, USA. Environ. Sci. Technol. 40 2108-2113.

Suresh, P.O., Dosseto, A., Hesse, P.P., Handley, H.K., 2013. Soil formation rates determined from Uranium-series isotope desiquilibria in soil profiles from the southeastern Australian highlands. Earth Planet. Sci. Lett. 379, 26-37.

Szalay, A., 1964. Cation exchange properties of humic acids and their importance in the geochemical enrichment of $\mathrm{UO}_{2}{ }^{2+}$ and other cations. Geochim. Cosmochim. Acta 28 $1605-1614$.

Tardy, Y., 1997. Petrology of Laterites and Tropical Soils. CRC Press, Boca Raton, 419.

Van Carlsteren, P., Thomas, L., 2006. Uranium-series dating applications in natural environmental science. Earth-Sci. Rev. 75, 155-175.

Waite, T.D., Davis, J.A., Payne, T.E., Waychunas, G.A., Xu, N., 1994. Uranium (VI) adsorption to ferrihydrite: application of a surface complexation model. Geochim. Cosmochim. Acta 58, 5465-5478. 